\title{
ENTRE EL PARLAMENTARISMO Y LA INSURRECCIÓN: LA MINORÍA REPUBLICANA EN LAS CORTES CONSTITUYENTES DE LA REVOLUCIÓN (1869-1871)
}

\author{
JORGE VILCHES \\ Universidad Complutense de Madsrid \\ jorge.vilches@cps.ucm.es
}

(Recepción: 22/01/2014; Revisión: 17/03/2014; Aceptación: 08/07/2014; Publicación: 26/11/2015)

1. IDENTIDAD Y OBSTRUCCIONISMO EN EL PROCESO CONSTITUYENTE.-2. FigUeRAS Y LA ATRACCIÓN DE LOS DEMÓCRATAS.-3. DEL PARLAMENTARISMO A LA INSURRECCIÓN.-4. Pi Y MARGALl Y LA DENUNCIA DEL PROGRESISMO.-5. LA DIVISIÓN DE LA MINORÍA REPUBLICANA.-6. CONCLUSIÓN.-7. BIBLIOGRAFÍA

\begin{abstract}
RESUMEN
La minoría republicana de las Cortes constituyentes de la Revolución (1869-1871) desarrolló una estrategia parlamentaria para obstruir las iniciativas de la mayoría gubernamental -lo que se denomina «obstruccionismo»-, y para hacer propaganda y marcar liderazgos y comportamientos políticos. Llevó a cabo un obstruccionismo técnico usando el Reglamento de Cortes, con numerosas mociones de censura y proposiciones, llamadas continuas a votaciones nominales, o el «filibusterismo» entre otras actuaciones. La minoría añadió a esto el obstruccionismo físico, consistente en entorpecer las sesiones con gritos, aplausos exagerados, discusiones o abandonos masivos. El obstruccionismo alimentó el antiparlamentarismo de los federales revolucionarios y abrió una brecha que resultó irresoluble en 1873. Al tiempo, en la minoría republicana se sucedieron tres liderazgos -Orense, Figueras y Pi y Margall- que también aportan elementos importantes para entender la búsqueda de identidad del republicanismo en el Sexenio.
\end{abstract}

Palabras clave: republicanismo; federalismo; posibilismo; Cortes; Sexenio Revolucionario; Primera República; parlamentarismo; oposición parlamentaria; obstruccionismo. 


\title{
BETWEEN PARLIAMENTARISM AND INSURRECTION: THE REPUBLICAN MINORITY IN THE CONSTITUENT CORTES OF THE REVOLUTION (1869-1871)
}

\begin{abstract}
The republican minority in the Constituent Parliament of the Revolution (18691871) developed a strategy to obstruct the initiatives of the government majority -what is called «obstructionism»- and to propagandize and mark leadership and political behavior. The minority used the technical obstructionism taking advantage the parliamentary Regulations with numerous motions of censure and proposals, continuous calls to nominal votes or the «filibuster», amongst other actions. The minority added the physical obstructionism, which consisted to interfere the sessions with screaming, exaggerated applause, discussions or massive dropouts. The obstructionism fueled the antiparliamentarism of the revolutionaries federal and opened a gap that proved unsolvable in 1873. Moreover, the republican minority had three leaderships -Orense, Figueras and Pi y Margall-, that contribute to understanding the search for identity of republicanism in the years followed.
\end{abstract}

Key words: republicanism; federalism, possibilism; Cortes; Revolutionary Sexenio; First Republic; parliamentary; parliamentary opposition obstructionism.

En teoría, en los sistemas fundados sobre el principio de representación política, la soberanía reside en la nación, máxime si está reconocido el sufragio universal, y se ejerce a través de la representación política en el Parlamento. Se crea así una conexión entre el titular originario de la soberanía y la entidad a la que se le confía el gobierno, que legitima y fundamenta el control del Parlamento sobre la acción gubernamental. El control parlamentario deriva del principio de separación e interdependencia de los órganos de soberanía, y consiste en la verificación de la acción del Gobierno respecto de sus fines constitucionales y de las directrices políticas del Parlamento. Esta fiscalización se asume como una técnica jurídico-constitucional de garantía y control de la adecuación de las medidas gubernamentales a la ley y a la distinta interpretación de la voluntad popular. En clave interna o institucional, el control parlamentario sirve para enmendar la acción gubernamental a través de la fiscalización y la cooperación, para impedir dicha acción a través del denominado «obstruccionismo»y, en última instancia, se utiliza para fortalecer o sustituir al Gobierno. En clave externa o pública, el control es usado para la propaganda de las ideas y personas del grupo, o bien para reforzar la cohesión o manifestar la división del mismo, incluso en la lucha por el liderazgo. La eficacia del control, por tanto, está en gran medida en el cumplimiento de los objetivos propagandísticos del grupo de 
diputados, y en la acotación del Gobierno a las normas y a la voluntad popular. Los instrumentos mínimos o básicos para llevar a cabo ese control son las preguntas e interpelaciones al Ejecutivo, las mociones o proposiciones de censura y confianza, las proposiciones no de ley, y la participación en los debates (1).

El obstruccionismo parlamentario fue una de las prácticas más extendidas en Europa y Estados Unidos durante el siglo XIX debido a la permisividad de los Reglamentos. Uno de los primeros episodios registrados de obstruccionismo fue en 1841, cuando el senador norteamericano G. W. Clay definió como «filibusterismo» a la prolongación del discurso parlamentario más allá de lo razonable para retrasar la aprobación de medidas legislativas. Esta práctica ya se hacía en la Cámara de los Comunes, cuando los líderes de la oposición en 1831, Robert Peel y Wilson Crooker pronunciaron 82 discursos entre los dos en quince días. El término «obstruccionismo» nació en dicha Cámara para definir la actitud de los diputados irlandeses, los Home Rulers, entre 1877 y 1881 . Aunque la práctica es anterior, en España se comenzó a utilizar el concepto en las Cortes en 1893, en un discurso de Nicolás Salmerón contra la decisión gubernamental de aplazar las elecciones municipales. Hasta 1918 los reglamentos españoles no previeron lo suficiente el obstruccionismo.

Las definiciones de obstruccionismo son variadas, pero todas coinciden en que es el uso desmesurado que hacen los agentes parlamentarios de los instrumentos técnico-jurídicos de carácter procedimental del reglamento, para retrasar, impedir u obstaculizar la adopción de medidas o acuerdos, y hacer propaganda de sus ideas y líderes. El obstruccionismo puede ser activo, cuando lo realiza la minoría, y pasivo, cuando lo lleva a cabo la mayoría parlamentaria. Además, el obstruccionismo puede ser físico, en referencia a la promoción de altercados entre diputados o abandonar de forma masiva los escaños; o bien obstruccionismo técnico, relativo al filibusterismo, al agotamiento de los turnos y tiempos, la presentación masiva de propuestas, a solicitar de modo abusivo el turno por alusiones, al empleo desmesurado o incorrecto de la llamada al Reglamento, a la solicitud constante de votación nominal, o la formulación excesiva de enmiendas.

Este trabajo analiza la estrategia parlamentaria de la minoría republicana entre 1869 y 1871, que formalmente fue para el control gubernamental en el cumplimiento de la Constitución y de la voluntad nacional, pero que en la práctica fue obstruccionista. El obstruccionismo se produjo de forma paralela a la definición del republicanismo y a su articulación como partido, lo que alentó el antiparlamentarismo y a los revolucionarios. Esto devaluó los métodos demo-

(1) Para el control parlamentario como forma de control político del Gobierno, véanse Montero y García Morillo (1984): 17-36, Aragón (1986) y LóPez Aguilar (1991). El papel de las minorías en la fiscalización es tratado por SÁNCHEZ NAVARRo (1995) y SERRA (2009). Un estudio muy completo sobre la teoría de la oposición parlamentaria y sus métodos en SÁNCHEZ NAVARRo (1997). El obstruccionismo como técnica parlamentaria en TORRES MURO (1993-1994), RidAuRA (1995) y GONZÁLEZ dE ZÁRATE (2012). 
cráticos y perjudicó a la República en 1873. El estudio de la minoría republicana, además, proporciona elementos para comprender la lucha por el liderazgo dentro del republicanismo y el origen de sus divisiones ideológicas.

\section{IDENTIDAD Y OBSTRUCCIONISMO EN EL PROCESO CONSTITUYENTE}

El decreto del Gobierno provisional del 9 de noviembre de 1868 estableció el sufragio universal masculino y la provincia como circunscripción electoral -siendo posible la división de esta en dos o tres si por el número de habitantes se debían elegir más de seis diputados-. Era el objetivo más ansiado por el Partido Demócrata desde su fundación casi veinte años antes. Lo entendían como un instrumento de transformación social y política, expresión de la voluntad popular, y condición imprescindible para la modernización y el progreso del país. El fin del sufragio censitario supondría a su entender el final de la corrupción electoral, del manejo desde el Ministerio de la Gobernación, y el peso de los caciques locales quedaría sujeto por la fuerza del pueblo (2). Las Cortes se convocaron para el 11 de febrero de 1869, fijándose la votación en los días 15 a 18 de enero. El gobierno no fue neutral; así lo había anunciado en el manifiesto del 25 de octubre de 1868 , y en el preámbulo del decreto de convocatoria, al decir que prefería que fueran elegidos los partidarios de la monarquía democrática.

El republicanismo organizó un Comité Nacional presidido por José María Orense, que animó a la constitución de comités en cada circunscripción, y que contaba con periódicos de alcance y tirada, como La Discusión y La Igualdad. Se eligieron 363 diputados. No obstante, hubo 66 elecciones parciales, por lo que un total de 389 diputados pasaron por las Cortes. De estos, 278 eran monárquicos y 28 carlistas (3). Los republicanos obtuvieron 81 actas, que quedaron en 71 por la revisión de la comisión parlamentaria pertinente y las renuncias de los que consiguieron doble elección, como Figueras, Castelar, o Pi y Margall. El grupo republicano contó en las sesiones previas a la aprobación de la Constitución con la presencia de entre 69 y 48 diputados. Tras la promulgación del texto la cifra se redujo bastante, casi a la mitad, salvo para votaciones muy señaladas.

Entre la reunión de Cortes y el comienzo del debate del proyecto constitucional, el 6 de abril de 1869, se produjo una auténtica avalancha de proposiciones de ley de los republicanos. Los ámbitos propuestos fueron los más controvertidos, como la abolición de las quintas o los impuestos. La minoría

(2) Sobre el republicanismo previo a 1868, véanse CASTRo Alfin (1994) y PEYRou TubERT (2007). Una buena relación bibliográfica sobre el republicanismo anterior a 1868 en PEYROU TUBERT (2011) y hasta 1931 en SuÁrez CORTINA (2011).

(3) Fuente Monge (2000): 183. 
republicana adoptó la estrategia del obstruccionismo para retrasar la actividad gubernamental y, al tiempo, resaltar las diferencias existentes entre los miembros de la coalición de Gobierno. Orense se ocupaba de la defensa de las proposiciones, y Castelar de mostrar los elementos que separaban a progresistas y demócratas de los unionistas. Existió un reparto de papeles oratorios: Figueras hizo los discursos doctrinales, Pi y Margall y Garrido los económicos, y Castelar los discursos mediáticos (4).

La identidad la marcaron a través de proposiciones de ley, como una de amnistía por delitos políticos, la incompatibilidad del cargo de diputado con el de empleado público, la supresión de los impuestos de consumo y personal, el desestanco de la sal y el tabaco, y la abolición de quintas (del 2 de marzo); o el matrimonio civil, y la suspensión de quintas y matrículas de mar (del 9 de marzo); o la concesión de ciudadanía a los extranjeros solicitantes, la prohibición de la prisión preventiva, y la edad de 20 años para acceder al sufragio activo (del 17 de marzo); u otra proposición para que no se celebraran quintas en determinados Ayuntamientos (del 23 de marzo); o para declarar libre el establecimiento de bancos agrícolas sin intervención gubernamental, o sobre la libertad de comercio, industria y oficio (del 29 de marzo). En suma, la minoría republicana presentó trece proposiciones de ley en veintiuna sesiones de Cortes.

Esto no solo marcaba su identidad, sino que obstruía la labor legislativa de la mayoría, ya que sumaron numerosas interpelaciones y preguntas, especialmente sobre cuestiones económicas, donde Tutau y Pi y Margall tuvieron el protagonismo, y alguna dedicada a resaltar que el monarquismo de la mayoría «traicionaba» el espíritu de la revolución. De aquí partieron preguntas acerca de Montpensier, presentada por Castelar para separar a progresistas y demócratas de unionistas, e intervenciones de Figueras, Soler y el propio Castelar sobre el sentido republicano de la Revolución de Septiembre.

El gobierno reaccionó usando su mayoría parlamentaria: el 16 de marzo presentó una proposición para formar comisiones legislativas que agilizaran el trabajo y evitaran el obstruccionismo. Castelar pronunció un discurso en contra sosteniendo que si se formaban dichas comisiones se inutilizaría la iniciativa legislativa de los diputados, y se condicionaría el texto constitucional. Finalmente, las comisiones se formaron el 18 de marzo, hasta cuatro -organización municipal y provincial, legislación electoral, legislación general, y orden público-, no sin que el día antes los republicanos aprovecharan para presentar tres proposiciones de ley.

Las intervenciones parlamentarias también sirvieron para señalar a los líderes del republicanismo y apuntar las líneas programáticas y de comportamiento

(4) La figura de José María Orense en Peyrou (2008) y Fuente Monge (2015). Sobre la figura de Pi y Margall, véanse Vilches (2001b), Gabriel Sirvent (2004) y CASTRo Alfín (2015). Acerca de la figura de Estanislao Figueras, véase DuARTE (2008), y de Castelar, VILCHES (2001c) y (2015), y VILLACORTA (2009). 
político, así como sus divisiones. Estaban conformes en que el gobierno debía ser parlamentario; es decir, que debía ser elegido por las Cortes como depositarias de la soberanía nacional, y en la reducción de los impuestos a dos -de aduanas y sobre la riqueza territorial, comercial e industrial-. Coincidían también en la separación de la Iglesia y el Estado, y en el carácter ilegislable de los derechos individuales. Había discrepancias en cuanto al encaje del socialismo en la democracia, un tópico desde 1860, y acerca de qué era el federalismo. Figueras y Castelar sostuvieron que no eran partidarios del «derecho al trabajo» ni al «reparto de la propiedad», asuntos sobre los que discrepaban Pi y Margall y Fernando Garrido. A esto era preciso sumar el «derecho de insurrección», invocado con frecuencia para el caso de que, en su opinión, no fueran respetados los derechos individuales, y que no fue suficientemente condenado por líderes parlamentarios como Figueras y Castelar.

En el debate sobre el proyecto constitucional, la minoría republicana centró su discurso en mostrar la incompatibilidad de la monarquía con la democracia, que venía a ser la clave elaborada en las Cortes por Ríos Rosas y Cristino Martos para sostener el nuevo régimen. El principio hereditario, dijeron, era incompatible con un sistema representativo basado en la soberanía nacional y en la voluntad y opinión públicas. Las facultades concedidas al rey -sanción legislativa, designación de ministros y disolución de las cámaras-, le daban prioridad sobre el Parlamento y la Nación (5). Esa misma soberanía nacional en democracia hacía anacrónico a un Senado basado en los privilegios. El proyecto, además, no protegía suficientemente los derechos individuales, que eran en su opinión el verdadero sentido de la Revolución. Por eso propusieron que fueran incluidos en el Preámbulo o en una declaración preliminar. En este sentido, el poder judicial no era independiente, la institución del jurado era obviada, así como la Milicia nacional. Las intervenciones en el debate constitucional marcaron el nuevo liderazgo en la minoría republicana, ya que Figueras y Castelar se alternaron en las intervenciones entre el 6 y el 13 de abril.

Los republicanos quisieron prolongar el debate sobre la totalidad para obstruir su aprobación, y presentaron una petición para que continuara la discusión mientras hubiera diputados que quisieran hablar. Perdieron la votación por 132 a 53, pero utilizaron dos instrumentos obstruccionistas más: el de la votación nominal, que retrasaba las discusiones al ocupar dicho sistema casi un tercio de cada sesión, y el consumo de la totalidad de los turnos de palabra. Además, presentaron numerosas enmiendas, algunas con contenido claramente ajeno a un texto constitucional. Fueron entonces los diputados de segunda fila, los

(5) Sobre el predominio del Parlamento sobre el rey en este periodo, véase MARCUELLO y PÉREZ LEDESMa (1996), y para su importancia en la Restauración, véanse CABRERA y ARRANZ (1995), los trabajos incluidos en CABRERA CALVo-Sotelo (1998), y Rey Reguillo y MARTORELl (2006). La importancia de la relación entre Corona, Gobierno y Parlamento en los reglamentos de Cortes del XIX hasta 1864 para la concepción de la monarquía constitucional, en MARCUELLO (2013). 
back-benchers, los que tomaron el protagonismo en las acciones parlamentarias, como Eduardo Palanca, Gil Bergés o García López, hasta el punto de que fue este último el que interpeló al gobierno sobre política general el 22 de abril, o Suñer el que sostuvo una enmienda al artículo 20 sobre la libertad religiosa.

El protagonismo de los backbenchers duró hasta que Rivero, presidente de las Cortes, impidió de mala manera que el republicano Serraclara hablara y llamó al orden a Tutau. En protesta, los republicanos salieron de la Cámara. Figueras presentó entonces una proposición para que las Cortes mostraran su «disgusto» por la actuación del presidente, pero la acabaron retirando tras oír las escusas de Cristino Martos. Al día siguiente, diputados progresistas, demócratas y unionistas presentaron un voto de confianza a Rivero, que fue aprobado por unanimidad, contando con los votos republicanos (6). Esto supuso la vuelta de los grandes nombres de la minoría -Figueras, Orense, Castelar y Pi y Margall- para debatir sobre los temas que marcaban la identidad republicana: la libertad de cultos, los derechos individuales, y la forma de gobierno.

Los dirigentes de la minoría consiguieron la presencia de prácticamente todos sus diputados para los debates sobre la cuestión religiosa de los artículos 20 y 21. Castelar, tras el éxito de su discurso del 12 de abril, aquel del «Dios del Sinaí», se encargó de defender la enmienda en nombre de la minoría, anunciando que votarían en contra de la primera parte del artículo 21 -mantenimiento del culto y clero-, y que se abstendrían de votar la segunda parte, la relativa a la libertad religiosa (7).

Fernando Garrido ya había anunciado que lo que unía a la minoría republicana era el reconocimiento y garantía de los derechos individuales y sus consecuencias; es decir, la soberanía nacional, y la elegibilidad y amovilidad de todos los que ejercían los poderes públicos (8). Así, Orense presentó una enmienda al artículo 22 para declarar ilegislables los derechos de expresión, reunión, asociación, manifestación pública, seguridad individual, culto religioso y propiedad. En realidad no se trataba solo de una cuestión constitucional, sino también que afectaba al «derecho de insurrección» que sostenía una parte del republicanismo: si no se podía hacer propaganda republicana y sus seguidores no se podían reunir, manifestarse o votar, tendrían que recurrir a la violencia (9). Dicho «derecho» estaba unido a su preocupación por el reconocimiento y dotación de la Milicia Nacional. Presentaron una proposición de ley para que se consignara en los presupuestos una cantidad de dinero para su armamento (el 29 de abril). Pretendieron, además, constitucionalizar a la Milicia Nacional por la puerta de atrás, mediante el establecimiento del derecho a adquirir, llevar y guardar ar-

(6) Diario de Sesiones de Cortes Constituyentes (en adelante DSCC), núm. 60, 27.IV.1869, pp. 1398-1399.

(7) Los discursos de Castelar en DSCC, núm. 67, 5.V.1869, pp. 1639-1646 y 1654-1655.

(8) DSCC, núm. 63, 30.IV.1869, pp. 1508-1513.

(9) DSCC, núm. 68, 7.V.1869, pp. 1679-1681. 
mas. Entre los firmantes de esa enmienda estuvieron Castelar, Abarzuza y Orense, quien la defendió diciendo que los individuos tenían el mismo derecho a defenderse que el Gobierno. A tal defensa se sumó uno de los incendiarios discursos de José Paul y Angulo diciendo que el «pueblo obrero» pedía armas para conservar la libertad ante la imposición de un rey (10). Luego presentaron dos enmiendas para que no se pudieran suspender las garantías constitucionales «en ningún caso, ni bajo pretexto alguno», que no salieron adelante.

El tema estrella del debate fue el relativo a los artículos 32 y 33, concernientes a la forma de gobierno, que Figueras y Castelar, ejerciendo ya de jefes de la minoría republicana en detrimento de Orense, accedieron a su discusión y votación conjunta. La decisión de esos dos líderes estuvo determinada por la cuestión de la indefinición de La Federal, y la disparidad de planteamientos entre los miembros de la minoría republicana. La forma monárquica de gobierno ya se había debatido con motivo del voto de gracias al Gobierno Provisional, con un discurso de Castelar del 24 de febrero, y a principios de marzo en un debate sobre los Borbones. Aun así, la monarquía democrática planteada por la coalición de septiembre era la clave del funcionamiento del régimen (11).

La batalla de la minoría republicana contra la articulación constitucional de la monarquía democrática se produjo en las sesiones del 12 y 14 de mayo. Presentaron hasta once enmiendas a los artículos 32 y 33 proponiendo las más variadas fórmulas e ideas, con el ánimo de obstruir el proceso y marcar su identidad. Propusieron que la forma de gobierno y el jefe del Estado fueran elegidos en plebiscito, que ningún poder fuera delegado hereditaria ni permanentemente, $o$ que el jefe del Estado fuera español de nacimiento. Además, la minoría presentó enmiendas que mostraban la divergencia de planteamientos: dos por la república federal, y otras dos por la república unitaria. En las firmas de sendas propuestas se mostraba la confusión en la minoría, porque si bien Castelar había firmado por la federal, entre los que proponían la unitaria estaban los que poco después formarían el grupo castelarino. Orense bautizó entonces a los federales que no cederían en sus creencias como «intransigentes». El debate entre republicanos estaba servido. El unitario Sánchez Ruano retiró su última enmienda, y dijo que la única República que podía arreglar los problemas políticos, sociales y económicos era una «república conservadora y seria». Para mayor confusión, la minoría presentó una última enmienda proponiendo la elección de un Directorio de cinco miembros elegidos por las Cortes; una propuesta que firmaron diputados con ideas y actitudes opuestas, como Paul y Angulo, Castelar o Eduardo Palanca.

Los discursos doctrinales los pronunciaron el 19 y 20 de mayo Pi y Margall y Castelar. Unos días antes, Fernando Garrido había expuesto los argumentos

(10) DSCC, núm. 69, 8.V.1869, pp. 1753-1755.

(11) Sobre la idea de monarquía en estas Cortes, véanse CALERo (1987) y VARELA SuANZeS (2006). La confrontación entre monarquía y república en estos años es tratada por LARIO GoNZÁLEZ (2007) y FUENTE MONGE (2007). 
populares republicanos y antimonárquicos: la incompatibilidad de la monarquía con la soberanía nacional y la democracia, la traición a la revolución el restaurar la forma monárquica, y la falsedad de que el pueblo no estaba preparado para la república (12). La doctrina republicana, sin embargo, la expusieron Pi y Castelar. Pi y Margall hizo una exposición de las contradicciones de la monarquía democrática, de la base filosófica e histórica del federalismo, y de las ventajas de la República federal basada en el pactismo voluntario y de abajo arriba. Castelar repitió los principios básicos de la democracia, su incompatibilidad con la monarquía, y el devenir de la Historia hacia la unión de la libertad y la democracia. Además, terminó su discurso de forma desordenada, pues mezcló la «confederación paneslavista», la intervención de Prim en México y la invitación a Serrano a que presidiera la República. De esta manera, Pi fue mucho más eficaz de cara al dogmatismo que iba adoptando el Partido Federal, al tiempo que Castelar iba marcando diferencias gracias a su pragmatismo y flexibilidad -lo que con el tiempo caracterizó al posibilismo- (13).

Sobre la mesa quedaba el asunto del comportamiento de las bases federales; es decir, si una vez aprobada la monarquía se levantarían en armas. Figueras defendió el derecho de insurrección si alguna de las libertades era violada, lo que era una amenaza para el caso de que consideraran que no podían hacer propaganda, reunirse o manifestarse en pro de la República. Orense expresó que si hubieran sabido que la revolución iba a ser monárquica, no la habrían apoyado. Paul y Angulo, federal intransigente, anunció que si se aprobaba la monarquía correría mucha sangre. Pi y Margall aseguró que la república «no saldrá nunca sino de las bayonetas del pueblo. Creer que puede salir de la Asamblea, es una locura, es un delirio» (14).

Con la aprobación el 20 de mayo del artículo 33, el de la monarquía, los debates constituyentes casi terminaron. La minoría republicana reunió entonces a casi todos sus efectivos, y los 71 votaron en contra. A partir de ahí se produjo el abandono de los que Orense había llamado «intransigentes», que ya despreciaban la vía parlamentaria y que iban a preparar un levantamiento armado.

\section{FIGUERAS Y LA ATRACCIÓN DE LOS DEMÓCRATAS}

Hasta la aprobación del artículo 33 la estrategia de la minoría republicana había sido la obstrucción de las iniciativas de la mayoría con el ánimo de retrasar su aprobación o cambiarlas, y utilizaron, como se ha visto, todos los medios

(12) DSCC, núm. 72, 12.V.1869, pp. 1869-1873.

(13) Un acercamiento al pensamiento y estrategia posibilistas en VILCHES (2012) y (2015).

(14) El discurso de Figueras en DSCC, núm. 76, 18 de mayo de 1869, págs. 2051-2061; el de Orense en DSCC, núm. 75, 17 de mayo de 1869, págs. 1999-2004; el de Paul y Angulo en DSCC, núm. 73, 13 de mayo de 1869, págs. 1930-1932; y el de Pi y Margall en DSCC, núm. 77, 20 de mayo de 1869, pág. 2101. 
que el reglamento de 1854 ponía en sus manos: proposiciones, enmiendas, interpelaciones, consumo de turnos de palabras y votaciones nominales. Esa estrategia estaba animada por una idea inspirada por Orense y perfectamente expuesta por Pi y Margall, que definió la tarea de su grupo, claramente obstruccionista: «Las minorías (parlamentarias) no deben hacer otra cosa más que ver la mejor manera de atacar y la mejor manera de defenderse, y harto sabido es que para esto lo mejor es encerrarse en el terreno de la negación» (15). El liderazgo parlamentario de Figueras cambió esto, que pasó a dirigir a la minoría republicana hasta la insurrección federal de 1869 (16). La estrategia fue la de resaltar las diferencias entre los demócratas y los unionistas para quebrar la coalición gubernamental.

Una vez aprobada la monarquía, los republicanos dejaron de presentar enmiendas al proyecto constitucional, abandonaron prácticamente las discusiones y no propusieron leyes. En diez días se aprobó el resto del texto. Una parte de los diputados republicanos dejaron las Cortes y se fueron a organizar el Partido a través de los pactos federales que se habían iniciado en mayo con el Pacto de Tortosa -así lo declaró García López el 26 de mayo en las Cortes.

La minoría republicana, que reunía ya a esas alturas de 55 diputados, votó en contra de la Constitución de 1869 el 1 de junio -que fueron 56 por el añadido del diputado Hidalgo el día siguiente-. Los debates internos habían sido intensos. Orense, Fernando Garrido, y Pi y Margall defendieron que los republicanos no debían aceptarla, y menos firmarla. Figueras y Castelar sostuvieron que el voto debía ser contrario, pero debían acatarla para mostrar que la República era una fórmula de orden que se sometía a los dictados de la soberanía nacional, y que avanzaría a través del trabajo parlamentario, la propaganda y las elecciones. No hubo acuerdo, y la minoría decidió que cada diputado actuara libremente. De los 55, hasta 39 firmaron la Constitución bajo la fórmula presentada por Figueras de acatamiento sin aceptación. Castelar aclaró que aceptarían todo lo proveniente de la soberanía nacional, pero nada del poder regio (17). Dejaron su rúbrica Castelar y los suyos, como Maisonnave, Moreno Rodríguez, Abarzuza y Juan Pablo Soler, y Figueras y sus seguidores, como Benot. Entre los que no firmaron estuvieron Orense y Pi y Margall, así como los que se levantaron en armas en octubre de 1869, como Blas Pierrad, Ramón Cala, Rafael Guillen, Serraclara, o Paul y Angulo.

Las Cortes aprobaron la regencia de Serrano el 15 de junio, no sin que la minoría republicana presentara tres enmiendas cuatro días antes proponiendo como alternativa la elección de un Consejo consultivo, una Regencia trina, o un regente responsable y amovible. No obstante, lo que estuvo presente en los discursos republicanos fue la actitud futura de los federales. El republicanismo

(15) DSCC, núm. 77, 19.V.1869, p. 2101.

(16) CASTELAR (1872): 42.

(17) DSCC. núms. 87 y 93, 1 y 7.VI.1869, pp. 2486-2487 y 2579-2582. 
en provincias, y con él muchos diputados, estaba dispuesto a seguir la revolución para imponer su forma de gobierno. Figueras aludía una y otra vez al derecho de insurrección si se menoscababan las libertades de propaganda, reunión y manifestación. Ese discurso tenía dos objetivos: amenazar al gobierno y contener a los suyos. Sin embargo, Figueras no podía hablar por el partido en provincias, que se organizaba sin su concurso ni autorización, solo por la minoría republicana, decía, que no se «saldrá de la legislación mientras se respeten los derechos individuales». Pero si no era así, «también lo he dicho y lo repito, la insurrección más que un derecho es un deber» (18).

La interinidad se basaba en mantener la coalición de progresistas, unionistas y demócratas hasta que se encontrara una dinastía para la revolución. Mientras tanto, la monarquía era solo un nombre. Las dificultades para encontrar un candidato adecuado, aceptado y aceptable, animaron la imaginación republicana, y también sirvieron para definir la estrategia de su minoría. Figueras se apoyó en Castelar para tomar las riendas de la minoría republicana, y decidieron llevar a cabo iniciativas que rompieran la mayoría gubernamental en su punto más débil; es decir, en el monarquismo circunstancial de los jefes de la democracia: Rivero y Martos. La idea era excitar las diferencias entre los dos extremos: el democrático y el unionista. Lo hicieron en dos campos: el ideológico y el ministerial. Por un lado, hicieron declaraciones que involucraran a los demócratas en la defensa del ejercicio de los derechos individuales, cuestión que les separaba de los unionistas y del ala derecha del progresismo, que veía en la ausencia de legislación al respecto un problema grave de orden público. Por otro lado, conocían las discrepancias entre los hombres de Rivero y Martos con los unionistas de Serrano y Ríos Rosas. Los demócratas consideraron que la conciliación era innecesaria una vez aprobada la Constitución, despreciaron formar parte de un gobierno junto a unionistas, y así se lo comunicaron al general Prim cuando ofreció ministerios a Rivero, Martos, Becerra y Echegaray.

La estrategia parlamentaria republicana dio sus frutos días después, el 5 de julio. Un grupo de demócratas y progresistas presentaron una proposición de censura al ministro de la Gobernación, el unionista Martín de Herrera, por un decreto que ordenaba la carrera judicial mediante la intervención del poder político. Esto quebrantaba a su juicio uno de los principios democráticos: la independencia del poder judicial respecto del gobierno para que los derechos individuales estuvieran garantizados. Martos defendió la proposición de censura, que extendió al Gobierno por todo lo que entendía política conservadora, y anunció la posibilidad de la formación de una nueva mayoría con la izquierda de la Cámara; es decir, con los progresistas de Ruiz Zorrilla, los demócratas y los republicanos. Para estos últimos era la escena deseada. Castelar confirmó su apoyo a la proposición de censura, no con el objetivo de sustituir al ministro de Gracia y Justicia, sino para que fuera sustituido por un demócrata. Esta decla-

(18) DSCC, núm. 94, 8.VI.1869, p. 2610. 
ración de Castelar se debía a que, puesto en conocimiento de Prim el tono de la proposición de censura y lo que se demandaba, encomendó a Ruiz Zorrilla el negociar con los republicanos su entrada en el Gobierno; concretamente, Pi y Margall en Hacienda, y Castelar en Fomento.

La minoría republicana discutió esta propuesta en una sesión particular. Garrido y Castelar se decantaron por la inteligencia con los progresistas, mientras que Pi y Margall se negó, pues a su entender hubiera supuesto transigir en los principios (19). La oferta de Martos aumentó las esperanzas de que se llegara a una República dividiendo al bloque monárquico, desplazar a la oposición a los conservadores de la Unión Liberal, y hacer que los demócratas se pasaran al campo republicano. La votación de la proposición de censura se celebró el 7 de julio, y dio una victoria numérica al gobierno Prim, con 144 frente a 95 votos (con 17 progresistas, 20 demócratas, 56 republicanos y 2 unionistas). Sin embargo, fue una victoria política para los promotores de la proposición de censura, ya que Martín de Herrera y Topete, ambos unionistas, dimitieron tras la votación (aunque el segundo sólo de su interinidad como ministro de Ultramar). El primero fue sustituido por Ruiz Zorrilla. Prim dio entrada por primera vez en el Gobierno a dos demócratas: José de Echegaray en Fomento, y Manuel Becerra en Ultramar.

Las esperanzas de los republicanos de romper el bloque gubernamental quedaron frustradas. Martos aseguró en un discurso en las Cortes que la coalición se mantendría sin abdicar en principio alguno. La coalición se fortalecía, dijo, con la entrada de Echegaray y Becerra en el Gabinete. Sánchez Ruano insistió en la imposibilidad de que existiera armonía en los acuerdos de Gobierno. Figueras atribuyó a Prim un deseo incumplido de romper con la Unión Liberal. Castelar advirtió a los demócratas de que les habían dejado los ministerios de menor importancia, y que su coalición con los conservadores daría como resultado el triunfo del elemento reaccionario (20). Fue entonces precisamente, en julio de 1869 , cuando los federales intransigentes iniciaron un levantamiento armado.

\section{DEL PARLAMENTARISMO A LA INSURRECCIÓN}

Una parte del federalismo en provincias sostenía, como Pi y Margall, Orense o Garrido, que la coalición gubernamental había traicionado la revolución al establecer una monarquía, lo que era incompatible con la soberanía nacional y la democracia, solo para conservar la alianza con la Unión Liberal y con la excusa de que el pueblo español no era republicano ni estaba preparado para la República. A esto añadían la defensa que diputados como Figueras habían he-

(19) VeRA (1886): I; 1014, y HENNESY (1966): 119.

(20) DSCC, núm. 126, 14.VII.1869. 
cho del derecho de insurrección, la convicción de que las elecciones eran y serían siempre falseadas, como señaló Orense, y que el parlamentarismo retrasaba el establecimiento de la fórmula que traería una nueva «Edad de Oro», $\mathrm{La} \mathrm{Fe}$ deral. Tampoco se puede soslayar la habitual frustración tras una revolución de la que todo se espera, la ambición política de los líderes locales, ni el romanticismo revolucionario que animaba a parte de la base social del federalismo, asentado en la tradición juntista española (21).

La idea de organizar el federalismo mediante pactos era, según ellos, hacer corriente a los españoles dicha organización, y, por otro lado, el levantar una estructura capaz de reconducir la revolución por la fuerza hacia La Federal. Los pactos fueron convocados y dirigidos por extraparlamentarios, y luego se sumaron los diputados. El primer pacto fue el de Tortosa, el 18 de mayo de 1869, que unía a las provincias de la antigua Corona de Aragón. Ante esta situación, y para no separarse de la militancia provincial, los diputados de esas circunscripciones firmaron un manifiesto de adhesión que escribió Emilio Castelar, diputado electo por Zaragoza y Lérida. Pi y Margall propuso la celebración de un Pacto Nacional entre los cinco pactos regionales celebrados -Tortosa, Córdoba, Castilla, Galicia con Asturias y Provincias Vascas con Navarra-, para controlarlos a través de un Consejo Federal. La propuesta no convenció a muchos, pero finalmente se constituyó con Pi y Margall como su portavoz, basado en dos pilares -el pactismo y el derecho de insurrección.

Mientras, las sesiones de Cortes se suspendieron por descanso estival hasta octubre. Se formó una Comisión Permanente, presidida por Rivero, con quince diputados -seis progresistas, tres demócratas, tres unionistas y tres republicanos, que fueron Sánchez Ruano, Sorní, y Pi y Margall-. La rebelión carlista que estalló ese mismo mes de julio fue abordada por Sagasta, ministro de la Gobernación, restableciendo la ley de orden público de 1821, modificando alguna de sus disposiciones, por la que se facultaba a los gobernadores civiles a reprimir toda manifestación contraria a la Constitución. A esto se añadió en la exposición de motivos que si no era suficiente dicha Ley, se suspenderían las garantías constitucionales. El anuncio cogió por sorpresa a los republicanos, que por boca de Pi y Margall pidieron veinticuatro horas para emitir un dictamen. Rivero, presidente de la Comisión Permanente, se lo denegó dada la urgencia, pero aseguró que dada la situación de suspensión de sesiones, el gobierno obraría «con prudencia y discreción restableciendo una ley liberal hecha por Cortes y contra los enemigos de las instituciones liberales». Los republicanos de la Comisión, a pesar de votar en contra, pusieron a disposición del orden público,

(21) Para el movimiento federal durante el sexenio revolucionario, véanse los clásicos de HENNESSY (1966) y JOVER ZAMORA (1991) y DUARTE (2001). En su vínculo con el socialismo Oliet Pala (1989) y PiQueras (1992). La diversidad del republicanismo en el XIX, se puede seguir en DUARTE y GABRIEL (2000). La formación y el desarrollo del partido republicano en PÉREZ ROLDÁN (2001). Una interpretación rígida de la división del republicanismo sobre el modelo de las culturas políticas en MiguEL GonZÁLEZ (2007). 
curiosamente, los batallones de Voluntarios que comandaban (22). Además, pasaron un escrito a la Mesa de la Comisión Permanente firmada por todos los diputados republicanos residentes en Madrid protestando porque entendían que el decreto violaba los artículos 11,30,31 y 34 de la Constitución -relativos a la prohibición de procesar ni sentenciar sino por juez o Tribunal, así como al establecimiento de tribunales extraordinarios, a la suspensión de garantías constitucionales, o a la aplicación de la ley de 1821-. Al tiempo, solicitaron la reunión de Cortes para pedir responsabilidades. Entre los firmantes estaban Figueras, Pi, Sorní, Sánchez Ruano, Fernando Garrido y Eduardo Chao. La propuesta republicana se desechó por diez votos a tres (23). Esto fue el pistoletazo de salida para que aquellos federales que esperaban un motivo para el levantamiento armado se lanzaran a las barricadas ejerciendo el «derecho de insurrección».

Al parecer, según contó años después Villalba Hervás, tras esa sesión de la Comisión Permanente, Rivero se entrevistó con Figueras para asegurarle que no se vulnerarían los derechos individuales si los republicanos no se salían de la legalidad. Confiado en esto, Figueras prometió a los representantes de los pactos que si los derechos eran violados por el Gobierno, los diputados de la minoría republicana acudirían cada uno a su localidad a dirigir el levantamiento (24). Ya en la Restauración, los escritores republicanos se responsabilizaron mutuamente del levantamiento de 1869. Lo cierto es que la insurrección estuvo muy desorganizada, y partió de una parte de la minoría republicana y de los representantes de los Pactos.

Uno de los directores de aquella revuelta fue el diputado y general federal Blas Pierrad. Organizó un «Centro de Acción Revolucionario» en Madrid, y anunció a Pi y Margall a mediados de agosto su intención de ir a Tortosa a iniciar el levantamiento (25). Probablemente se lo comunicó a Pi porque presidía el Consejo Federal del Pacto Nacional y, por tanto, era el coordinador de los pactos regionales. Pi se negó a dar orden revolucionaria alguna, pero no hizo nada más. En la manifestación de los federales tarraconenses se profirieron gritos contra la Constitución y se exhibieron banderas y pancartas contrarias a la legalidad; todo esto contravenía el decreto publicado por Sagasta. Además, terminó con el asesinato del secretario del gobierno civil. La revuelta fue sofocada ese mismo día 20. Siete días después se formó una junta revolucionaria que en nombre del Pacto de Tortosa levantó a unos 8.000 hombres armados en Cataluña (26). La revuelta se extendió por varias regiones.

(22) Sorní comandaba un batallón de voluntarios en Madrid. Actas de la Comisión Permanente (en adelante ACP; apéndice 1. ${ }^{\circ}$ al núm. 128 del DSCC), 22VII.1869.

(23) ACP, 29.VII.1869.

(24) Villalba Hervás (1899): 75. Morayta (1895): 687-695. Pi y Margall y Pi y ARSUAGA (1902): IV; 561. EsTÉVANEZ (1975): 189.

(25) VERA Y GONZÁlEZ (1886): II; 22. RisPA Y PERPIÑÁ (1932): 276.

(26) VERA Y GONZÁLEZ (1886): II; 33. 
La insurrección obligó a Sagasta a comparecer ante Comisión Permanente. Sorní, único diputado republicano que desde el 23 de septiembre quedaba en dicha Comisión, le acusó de haber violado el artículo 56 de la Constitución con la detención de Blas Pierrad. Su ingreso en prisión se debía, según Sagasta, a haber faltado a su deber militar de impedir el desorden e infringido la ordenanza militar por ausentarse de la capitanía general sin la licencia del Gobierno y sin presentarse a la autoridad militar en el acto a llegar a Tarragona (27).

El desconcierto en la minoría republicana fue completo. Orense había marchado a Salamanca para encabezar el movimiento pero se retractó. Figueras no dio señales de vida. Pi y Margall y Castelar estaban fuera de Madrid. El rechazo al levantamiento fue implícito, no así la condena a la suspensión de garantías y a la represión. Castelar escribió el 28 de septiembre un manifiesto de protesta en nombre de la minoría, denunciando que el Gobierno era «arbitrario» $\mathrm{y}$ «dictatorial» por violar los derechos individuales, traicionando así el espíritu y sentido del movimiento de 1868. La minoría republicana, decía, acusaría al Gobierno en la reanudación de las sesiones, y si no se admitía, se retiraría de las Cortes y no acudiría a las elecciones que pudieran celebrarse (28). El republicanismo en provincias seguía aún en revolución, creyendo que ese estado de ánimo entre los suyos inclinaría la balanza política a su favor porque los otros partidos acabarían por ceder a la presión. Sin embargo, el fracaso de la vía insurreccional supuso un quebranto en la minoría republicana. La ambigüedad usada por los líderes parlamentarios era calculada porque sentían que si no abandonaban las Cortes perderían el favor de la mayoría del partido, ganada ya por el federalismo intransigente. El fracaso de la violencia a finales de 1869 provocó que surgiera una tendencia de rectificación del republicanismo que tomó cuerpo a principios de 1870 , como se verá más adelante.

\section{Pi y Margall y LA DENUNCIA DEL PROGRESISMO}

Fracasada la insurrección, pero aún viva en algunas localidades, Prim, presidente del Gobierno, pidió la suspensión de las garantías constitucionales el 2 de octubre; un día después de reanudarse las sesiones de Cortes. Para entonces ya había en Madrid una veintena de diputados republicanos, encabezados por $\mathrm{Pi}$, Castelar, Figueras y Orense. Aquel mismo día, Sagasta comunicó a las Cortes la disolución de los Cuerpos de Voluntarios de Tarragona, Tortosa, Barcelona y Martorell. La sesión no terminó sin que antes Figueras anunciara la defensa de la acusación al Gobierno por haber encarcelado a los diputados Pierrad y Serraclara.

(27) ACP, 25 y 28.IX.1869.

(28) La Discusión, 29.IX.1869. 
La sesión del día 3 mostró la confusión en la minoría republicana. La coalición gubernamental presentó un voto de gracias a la Milicia de Madrid, también firmado por el diputado Sorní, por cumplir su deber de mantener el orden. Toda la minoría, hasta 17, votó en contra, menos Sorní, y Figueras y Díaz Quintero atacaron al Gobierno. Los diputados de la mayoría aprovecharon para señalar el desconcierto reinante en el campo republicano. Después se discutió el dictamen de la comisión sobre el proyecto de ley de suspensión de garantías constitucionales. Intervinieron los cuatro diputados republicanos más señalados del momento: Pi y Margall, Castelar, Figueras y Fernando Garrido. El argumento general fue que la insurrección había sido provocada por el Gobierno al impedir manifestaciones contrarias a la Constitución, lo que limitaba las libertades, al intentar la coronación de un rey extranjero, y debido al descontento ante una revolución que consideraban frustrada. Todo esto, dijeron, suponía un «giro conservador», en expresión de Figueras, hacia una «dictadura», según manifestó Castelar, que mostraba la deriva de progresistas y demócratas hacia el conservadurismo de los unionistas (29).

En el momento en el que se aprobó el primer artículo de la autorización para suspender las garantías constitucionales, el 5 de octubre, Castelar, comisionado por la minoría republicana, anunció que se retiraban hasta que la ley de suspensión de garantías fuera derogada. Los diputados republicanos fueron saliendo de la sala, menos Castelar, que oyó cómo Prim le pidió en cuatro ocasiones que reconviniera la postura de su grupo. La retirada fue decidida en una reunión de la minoría, hasta el momento en el que se levantara la suspensión de las garantías constitucionales. De todas maneras, para entonces solo iban a las sesiones de Cortes menos de veinte republicanos.

Pocos días después, la presidencia del Consejo de Ministros pasó a las Cortes una comunicación en la que daba la relación de los diputados que se habían alzado en armas. Eran un total de dieciocho, entre los que destacaban José María Orense, Paul y Angulo, José Fantoni y Manuel Carrasco, que huyeron del país; el general Blas Pierrad y Serraclara, que fueron encarcelados; Rafael Guillén, que murió. A estos los que tomaron parte en juntas revolucionarias pero no cogieron las armas: siete en total, todos de segunda fila. Además, se detuvo de forma preventiva a Eduardo Benot y se investigó a seis más, entre los que estaba Ramón de Cala -luego redactor de El Combate, de Paul y Angulo- (30). Se formó una comisión para informar sobre estos diputados, presidida por el progresista José de Olózaga (31). Las Cortes privaron de su escaño a Joaritzi, Álvarez Acevedo, Ameller y Caymó; y el asunto no llegó a más porque fueron absueltos en su mayoría, salvo Pierrad que pasó una temporada en la cárcel.

(29) DSCC, núms. 130, 131 y 132, 3, 4 y 5.X.1869, pp. 3774-3807, 3820 y 3842-3846, respectivamente.

(30) Fuente Monge (1993: 891).

(31) DSCC, núm. 136, 9.X.1869. 
Pi no había estado de acuerdo con la retirada de la minoría de las Cortes y siguió haciendo tareas parlamentarias, como fue la proposición que hizo llegar a la Mesa para hacer una adición al proyecto de ley sobre quiebras de ferrocarriles (32). En realidad, la participación institucional era la postura más provechosa ante la realidad de que no controlaban el partido en provincias. Esto no quería decir que Pi y Margall no fuera contrario a la revolución para conseguir la federación, y que no justificara la insurrección, sino que le desagradaba el momento y la forma. Pi consiguió convencer a los diputados republicanos no encausados, y presentes en Madrid, que decidieran la vuelta a las Cortes. Se reunieron los días 21 y 22 de noviembre, y acordaron el regreso. De los líderes republicanos, Figueras se mantuvo al margen, mientras Castelar comenzaba a recorrer el camino de negación del federalismo y de la afirmación del republicanismo conservador. En esas circunstancias, Pi y Margall, de ideas claras, jefe del Pacto Nacional, y con el partido rendido formalmente a sus planteamientos pactistas, se hizo con las riendas de la minoría republicana. El pulso entre Pi y Castelar, cuyo primer encontronazo había sido por la cuestión del socialismo en la democracia en 1864, se reanudó entonces. Pi convenció de la conveniencia del regreso argumentado que era muy probable la elección de Tomás de Saboya como rey de España, y que era necesario estar en las instituciones de cara a las elecciones municipales y de diputados (33).

Castelar fue el encargado de presentar el manifiesto de vuelta a las Cortes, pero el texto omitía el lenguaje y las actitudes radicales, entre otras, la palabra «federal», lo que disgustó a la mayoría del grupo -40 votos a 7 -. La segunda redacción no satisfizo en la explicación del federalismo ni en la descripción de la futura actitud política. La tercera versión combinó el lenguaje de la facción intransigente con el parlamentarismo, de manera que llamaba a luchar pacíficamente por La Federal en los «Estados Unidos de la antigua Iberia independiente y libre», y terminaba con un «Salud y fraternidad» (34). El manifiesto lo firmaron 40 diputados. La prensa liberal, con La Iberia y El Imparcial a la cabeza, quedó defraudada porque esperaban un texto más moderado.

La vuelta a las Cortes fue inaugurada por Pi y Margall, pero no para explicar el regreso, sino para justificar el alzamiento federal con los mismos argumentos de octubre: el derecho de insurrección ante la provocación gubernamental y su ataque a los derechos individuales (35). Detrás de esta denuncia estaba la necesidad de que el Gobierno retirase la suspensión de las garantías constitucionales, pues con ellas había disuelto ayuntamientos y diputaciones republicanas que no habían sido repuestas aún a pesar de que la insurrección había terminado. El problema estaba en que debían celebrarse pronto elecciones municipales,

(32) DSCC, núm. 147, 26.X.1869, pp. 4076-4077.

(33) La Discusión, 20, 21 y 23.XI.1869.

(34) La Discusión, 26.XI.1869.

(35) DSCC, núm. 169, 27.XI.1869, pp. 4424-4429. 
y era facultad de los ayuntamientos el otorgar células de vecindad cada mes de enero, sin la cual no se podía votar. De esta manera, Castelar denunció en las Cortes que el objetivo de la suspensión de las garantías constitucionales era la manipulación electoral. Y Figueras solicitó que los ayuntamientos depuestos fueran juzgados por los Tribunales ordinarios y repuestos antes de cualquier elección, si no la considerarían ilegal y volverían a la insurrección (36). Aun así las elecciones se convocaron, la minoría republicana denunció, pero nadie se levantó en armas.

La nueva estrategia marcada por Pi y Margall para la minoría republicana tenía dos pilares. En primer lugar, la crítica debía centrarse en el Partido Progresista, señalando que había perdido su identidad como representante de la voluntad nacional y, en consecuencia, su base social, el apoyo que tuvo en el reinado isabelino, cuando hizo suyas las reivindicaciones económicas y políticas más populares. Esto se debía al compromiso con la monárquica y conservadora Unión Liberal, lo que animaba a la ruptura a los progresistas-demócratas que desde finales de 1869 se hacían llamar «radicales». El segundo pilar era la organización de un partido legalista volcado en la propaganda, con un ideario reconocido basado en el federalismo pactista, cuya dirección coincidiera con la de la minoría republicana.

La crítica al Partido Progresista la llevó a cabo a través de interpelaciones y proposiciones de censura, hasta seis entre noviembre de 1869 y junio de 1870 , cuyo fundamento era la denuncia de su supuesta deriva conservadora. La proposición de censura del 27 de noviembre de 1869 marcó el argumento principal: el progresismo había dejado de ser un partido de progreso, para convertirse en un elemento de la reacción, traidor a la voluntad del pueblo. En esta ocasión la proposición la defendió Pi, marcando el liderazgo, y la perdieron por 146 votos a 35, que era el número de diputados republicanos que asistía a la cámara. En la misma línea fue la interpelación de Castelar, el 11 de diciembre, que acusaba a los progresistas del Gobierno de haber convertido una democracia en una dictadura.

Figueras sumó una segunda interpelación cuando se produjo la crisis de gobierno de enero de 1870 por la negativa de Tomás de Saboya de aceptar la Corona de España, que se había saldado con la salida de Ruiz Zorrilla y de Martos del Gabinete. El argumento fue que la crisis se debía a la disparidad de principios entre progresistas-demócratas y unionistas en cuanto al ejercicio de los derechos individuales, que era el alma de la revolución de 1868, algo en lo que insistió la minoría desde la aprobación del artículo 33 del proyecto constitucional, referido a la monarquía. En esta batalla por los principios apoyaron el conocido entonces como «Proyecto de Constitución de Puerto Rico», el de abolición de la esclavitud, y el de dotación del culto y el clero -todos en

(36) DSCC, núms. 180, 186 y 205, 11 y 18.XII.1869, y 29.I.1870, pp. 4657-4666, 48174818 y $5293-5303$, respectivamente. 
confrontación con los unionistas-, y apoyaron al ministro demócrata de Fomento, José de Echegaray, en una proposición de censura conservadora sobre la enseñanza de la religión en las escuelas públicas. Y votaron a su favor en la proposicion de confianza posterior. Castelar explicó este voto pro-gubernamental: no habían apoyado al ministro, sino a la idea, a la enseñanza laica y a la separación de la Iglesia y el Estado. Lo definió muy bien al decir: «Coalición de partidos, no; coalición de ideas, sí».

En esa misma estrategia rupturista, la minoría republicana presentó en abril de 1870 hasta cuatro proposiciones de censura contra el ministro de la Gobernación, Nicolás María Rivero, viejo líder demócrata que sostenía la alianza con los unionistas de Serrano, por la represión de las algaradas en contra de las quintas -una violencia que protagonizaron una vez más los federales de provincias-. Pi y Margall presentó otra proposición de censura, el 20 de junio, esta vez ideológica y económica, contra la aprobación de la reforma del Código Penal que regulaba los derechos individuales, y por la venta de los bonos del Tesoro al Banco de París, y el acuerdo de crédito con la casa Rothschild.

La segunda parte de la estrategia -la formación de un partido federal legalista y la unificación de direcciones en la minoría-, se alimentaba de la esperanza de tener una estructura preparada para el caso de que el régimen derivara hacia una República por la imposibilidad de encontrar una dinastía para la Revolución. A comienzos de 1870, Tomas de Saboya rechazó la Corona de España; era un fracaso más (37). La esperanza de los federales era mostrar que la única salida para los progresistas, si realmente seguían siendo un partido popular y consecuente con su trayectoria y con la revolución, era la República.

Figueras y Castelar desconfiaban de la reorganización del partido en provincias; preferían la actividad parlamentaria, la propaganda y la actividad para las elecciones -el sistema tradicional-, antes que alimentar una estructura intrínsecamente incontrolable y revolucionaria. Todavía no se habían planteado la necesidad de crear una estructura nacional y permanente de movilización y acción democráticas para enfrentarse a la vida política, no solo a las elecciones. Sin embargo, Pi, como presidente del Pacto Nacional, convocó una Asamblea Federal para marzo de 1870. De ahí salió un manifiesto escrito por Pi en el que jerarquizaba la organización con un Directorio compuesto por Orense, Figueras, Castelar - ninguno de estos dos acudió a la Asamblea-, Pi y Vicente Urgellés. Señalaba, además, que la vía para acceder al poder era la propaganda y el parlamentarismo. De forma contradictoria, sumó días después un manifiesto definiendo el federalismo por el pacto sinalagmático y conmutativo; una fórmu-

(37) Sobre las candidaturas italianas, véanse los clásicos PAVÓn (1972) y SAGRERA (1959), y Pascual SASTRe (2001). Una interpretación interesante de la imagen pública de Amadeo de Saboya en Mira ABAD (2011). La candidatura Hohenzollern, en RUBIO (2011). La candidatura de Espartero, en SÁEz Miguel (2011). El conflicto de las candidaturas entre los partidos de la coalición, en VILCHES (2001a). 
la basada en la insurrección espontánea y local para la formación del Estado federal, y que desembocaría en el caos cantonalista de 1873. Esta fórmula agradó a los líderes provinciales del federalismo, que vieron en ella la continuidad y el instrumento de sus ambiciones locales. De esta manera, Pi unificó la dirección del partido y de la minoría bajo su mandato.

Esto tuvo su contestación muy pronto. El periodista Manuel de la Revilla y el diputado Sánchez Ruano reunieron a los parlamentarios que habían apoyado el primer manifiesto de Castelar para la vuelta a Cortes; aquel que moderaba el republicanismo. Elaboraron un manifiesto para reconducir el federalismo pactista de la Asamblea, y convertir al republicano en un partido de gobierno. Con este objetivo se reunieron seis diputados, todos castelarinos -Abarzuza, Soler, Moreno Rodríguez, Rebullida y Prefumo-, y Sánchez Ruano, quien decía contar con el apoyo de quince diputados más. A estos se sumaron representantes de la prensa, entre los que destacaron Rivera del Gil Blas, Pablo Nougués de El Pueblo, Bernardo García de La Discusión, Andrés Mellado de La Igualdad, y Joaquín Martín de Olías de La Justicia Social. El 7 de mayo de 1870 se publicó la llamada «Declaración de la prensa republicana». Para empezar intentaba definir el federalismo como una mera descentralización administrativa reglada por las instituciones, y rechazaba el pactismo de Pi y Margall por medieval, utópico y peligroso para la unidad de España. Las ideas socialistas del federalismo pimargalliano no encajaban en la democracia. Frente a ellas había que defender el mutualismo y el asociacionismo obrero. Por último, era preciso abandonar el derecho de insurrección, contrario a la idea de extender los principios democráticos entre la población a través de la actividad propagandística.

\section{LA DIVISIÓN DE LA MINORÍA REPUBLICANA}

El ataque a la jefatura de Pi y Margall fue claro. En respuesta, este convocó el 10 de mayo de 1870 a los diputados residentes en Madrid para que firmaran un manifiesto que presentó en nombre del Directorio. Acudieron a la cita 32 diputados, entre ellos Figueras, Benot, Chao, Pi, Sorní, Garrido, Moreno Rodríguez, Maisonnave, Castelar y Tutau. El manifiesto se reafirmaba en el federalismo pactista y despreciaba la Declaración diciendo que solo era la expresión de los periódicos. Castelar contestó que la Declaración cabía en el partido. La discusión se prolongó hasta que se votó que una Asamblea Federal decidiera si el texto era admisible. Tampoco se resolvió nada, pues hubo un empate a 11 y 6 abstenciones, la de Castelar entre ellas. La noche de ese mismo 10 de mayo, Pi y Margall redactó un escrito de adhesión a su propio manifiesto, pero tan solo consiguió 19 rúbricas. Hubiera sido el momento para que Castelar y Figueras recuperaran la dirección del republicanismo, pero renunciaron a dar la batalla en la organización del partido fuera de las Cortes, dejándolo en manos de Pi y Margall y de los intransigentes. No obstante, la minoría estaba partida y las 
diferencias se vieron en el debate sobre el proyecto de ley de organización municipal y provincial. Castelar defendió la descentralización repitiendo los principios de la Declaración. Pi y Margall, en lugar de contestar el proyecto legislativo, respondió a Castelar formulando el federalismo pactista. A esto le siguió el debate entre otros dos republicanos: Sánchez Ruano y Tutau (38).

La política quedó otra vez fuera de las Cortes gracias a una proposición del demócrata Martos, presentada el 21 de junio, para suspender sus sesiones hasta el 30 de octubre. La minoría se mostró conforme siempre que se aprobara antes la ley electoral, y así elegir los ayuntamientos y diputaciones disueltos tras la última algarada federal. Así se acordó y se suspendieron las sesiones dos días después. Ese tiempo de descanso parlamentario marcó el destino de la Revolución. Tras la aceptación y rechazo de Leopoldo Hohenzollern Sigmaringen al trono de España en julio de 1870, le siguió la proclamación de la III. ${ }^{a}$ República en Francia, el 4 de septiembre, y la caída por tanto de Napoleón III. El conjunto hizo creer a muchos federales que había llegado el momento de otro levantamiento armado. El Directorio, acudiendo a los precedentes de octubre de 1869 y abril de 1870 , creyó que se saldaría con un nuevo fracaso, y pensó que podía controlar a los impacientes a través de tres medidas. La primera fue apaciguar al partido con un manifiesto de términos muy imprecisos, hablando de la próxima caída de la monarquía en Europa, y asegurando que la diplomacia de los reyes sería sustituida por el pacto entre los pueblos para levantar los «Estados Unidos de la Europa libre». A esto añadieron que la «República federal» en España vendría gracias al ejercicio de los derechos individuales y al sufragio universal, lo que era un llamamiento a no tomar las armas (39). La asunción del lenguaje radical facilitaría la identificación de los seguidores impacientes con los líderes, facilitando así su control. Consolidaron esto con la convocatoria de una manifestación en Madrid el 8 de septiembre, a la que según La Discusión acudieron 20.000 personas, y que recorrieron las calles desde el monumento al Dos de Mayo hasta la Plaza de Oriente, donde terminó con los discursos moderados de Castelar y Figueras.

El refuerzo de la estrategia parlamentaria fue poner en valor el trabajo de la minoría. Los miembros de la Comisión Permanente -Pi y Margall, Sorní y Sánchez Ruano-, solicitaron tres veces la reunión de las Cortes para que el gobierno explicara las negociaciones en la cuestión dinástica (40). A esto, Pi y Margall, Figueras y Castelar, llamados ya el «triunvirato», añadieron un manifiesto para reunir a todos los diputados republicanos. El texto mezclaba la relevancia del parlamentarismo, aludiendo a la importancia de las Cortes como representantes auténticos de la soberanía nacional desde 1812, con el programa popular de La Federal; esto es, que la República federal acabaría con la centralización,

(38) DSCC, núms. 278, 279, 282 y 283, los días $11,12,16$ y 17.V.1870, respectivamente.

(39) La Discusión, 7.IX.1870.

(40) La Iberia, 6, 10 y 24.IX.1870. 
las quintas, los impuestos abusivos, el militarismo y el clericalismo, al tiempo que garantizaría los derechos individuales y la unidad nacional. Reunieron 64 firmas, lo que venía a ser una recuperación del número de diputados republicanos presentes en las primeras sesiones de las Cortes constituyentes (41).

La tensión entre los que querían levantarse en armas y los parlamentaristas, instalada desde octubre de 1869, llegó entonces a su punto culminante. Cuando las Cortes reiniciaron sus sesiones, el 30 de octubre de 1870, el intransigente Paul y Angulo presentó una proposición para que antes de seguir las sesiones se confirmaran los poderes de los diputados por sus respectivas circunscripciones. Aprovechó para criticar la vía parlamentaria que habían adoptado los jefes de la minoría republicana, y llamó a las armas. La mayoría vota en contra y los republicanos se abstuvieron menos Fernando Garrido, Ramón Cala, García López, Suñer, y el propio Paul y Angulo. Esta votación marcó el parlamentarismo de la mayoría de los diputados republicanos, pero también su tibieza a la hora de condenar la violencia.

El 3 de noviembre, Prim, presidente del Gobierno, anunció en las Cortes la aceptación de Amadeo de Saboya. Era ya algo conocido, por lo que la minoría republicana presentó una proposición de censura, defendida por Castelar y Figueras, denunciando la usurpación de la soberanía al ofrecer la Corona a varios candidatos sin conocimiento público. La minoría sumó a sus 40 diputados los votos de cuatro unionistas contrarios a Amadeo: Ríos Rosas, Vega de Armijo, Alarcón y Méndez Vigo. Y de nuevo votaron juntos, más los carlistas, contra la proposición de Ruiz Zorrilla, presidente de las Cortes, de suspender sesiones hasta el 16 de noviembre con un orden del día fijado.

La sesión de aquel día, destinada a elegir rey, la planteó la minoría como la escenificación de una traición. Primero apelaron a la dignidad política de los diputados. Para ello Figueras y Sorní preguntaron a la presidencia si los diputados iban a votar con libertad, máxime si había fuerzas militares apostadas para asegurar el orden. Castelar intentó hacer un discurso al respecto, pero Ruiz Zorrilla le negó la palabra. El resultado de la votación es conocido, y contó con la división de los votos republicanos: 60 por la república federal, 2 por la república española y 1 por la república. A partir de ese momento, la minoría republicana intentó obstruir la sesión negándose a suspender las sesiones hasta que volviera la comisión parlamentaria enviada a Italia, e interrumpiendo constantemente el discurso de Ruiz Zorrilla.

Lo único que le quedaba por hacer a la minoría era obstaculizar el desarrollo legislativo, ya que el Gobierno quería disolver el Parlamento antes del advenimiento de Amadeo de Saboya. Si las Cortes reunidas en 1869 continuaban vivas, la minoría creía que aún quedaba una posibilidad de revocar la elección del príncipe saboyano. La minoría regresó al obstruccionismo de la primera etapa de la constituyente, obstaculizando reglamentariamente el desarrollo de

\footnotetext{
(41) La Discusión, 25.IX.1870.
} 
las sesiones a través de la presentación de censuras y proposiciones. Se reunieron todos los días a partir del 13 de diciembre, e hicieron un llamamiento en la prensa del partido a los diputados ausentes «para asuntos de suma urgencia y del mayor interés» (42). En la reunión del 13 decidieron presentar dos proposiciones de censura; una contra el presidente de las Cortes por su comportamiento en la última sesión, y que sería defendida por Castelar, y otra contra la política general del Gobierno, que sostendría Pi y Margall. Nombraron una comisión compuesta por Díaz Quintero, Benot y Soler para la elaboración de proposiciones, hasta ocho, que se repartieron para su defensa en la reunión de la minoría del día 16 entre Sánchez Ruano, Robert, Pi, Castelar, Gil Bergés, García López, La Rosa y Moreno Rodríguez (43).

En la primera sesión de la reanudación de las Cortes, el día 15, Figueras pidió la lectura del Reglamento para sostener que tal día no podía haber sesión porque el presidente de la Cámara no había fijado el orden del día en la última sesión. Le secundaron Sorní -que para alargar su discurso hizo una disquisición sobre la raíz latina de «Acta»- y Díaz Quintero. Y para prolongar más el incidente, la minoría pidió que el voto fuera nominal. Ruiz Zorrilla entró en un juego dialéctico con Figueras, auxiliado por Sorní, que consumió la sesión con temas menores como si las cartas de Víctor Manuel II y Amadeo de Saboya que se leyeron en las Cortes tenían traducción oficial; o por qué habían sido publicadas en La Gaceta, cuando lo correcto era haberlas llevado antes al Parlamento. Lo mismo hizo la minoría cuando Martos presentó una proposición para que la Cámara mostrara su satisfacción por la carta de aceptación de Amadeo, y diera un voto de gracias a la comisión parlamentaria que viajó a Italia. Figueras, para contrarrestarla y retrasar el proceso legislativo, presentó otra para que se deliberara sobre dicha proposición. Con gran habilidad, y aprovechando la ingenuidad de Ruiz Zorrilla, desvió el debate hacia la libertad de expresión y la política de orden público que llevaba a cabo el Gobierno. Mientras, los diputados republicanos no dejaban de proferir voces o aplaudir, y las alusiones permitieron que otros pidieran la palabra. A esto se sumó otro de los discursos incendiarios de Paul y Angulo, que sacó a Rivero de sus formas educadas, produciéndose un intercambio de insultos y acusaciones. Y así transcurrieron las horas reglamentarias de la sesión, hasta cinco, sin que nada se adelantase. No obstante, la mayoría gubernamental no consintió que volviera a ocurrir: en la sesión del 16 de diciembre desecharon las proposiciones obstruccionistas sobre el Reglamento y negaron la palabra a Castelar por votación nominal.

La estrategia obstruccionista continuó cuando la mayoría propuso que las Cortes duplicaran sus sesiones y trabajaran los fines de semana para terminar la obra legislativa antes del juramento del príncipe Amadeo; en total cinco proyec-

(42) La Igualdad, 14.XII.1870 y La Discusión, 15.XII.1870.

(43) La Correspondencia de España, 13 y 15.XII.1870; La Época, 14.XII.1870; El Imparcial, 15.XII.1870; La Discusión, 16 y 17.XII.1870. 
tos de ley. El proceso se repitió: Figueras tomó la palabra, pidió la lectura de normas -en este caso, artículos de la Constitución-, y condujo el debate hacia la política general, con alusiones a personas y temas que provocaron la intervención de otros diputados. Tuvo éxito, y el debate siguió el 23 de diciembre de forma mucho más extensa (44). Finalmente, a las tres de la mañana del 24 se aprobó la «proposición Romero Robledo», que autorizaba al gobierno a formar comisiones legislativas que agilizaran en unos días los proyectos de ley. Los republicanos no asistieron a la votación: se marcharon fuera del salón.

La tensión entre parlamentaristas e insurreccionales fue tan evidente, que algunos ministros pidieron en las Cortes una declaración pública sobre su actitud; es decir, si iban a seguir en la legalidad o no. La necesidad de mantener la unión de los republicanos en aras a mostrar fortaleza, fue una quimera que perjudicó gravemente al republicanismo. En este sentido, los líderes de la minoría y del Directorio decían que entendían la «justicia» y la «razón» del derecho de insurrección, pero lo desechaban por prudencia. Este argumento era tan débil como inútil, pues no se trataba de una declaración tajante en defensa de la democracia, la organización del partido, la propaganda y el ejercicio de los derechos individuales, sino que se limitaba a poner en cuestión el momento o las circunstancias elegidas, lo que era para muchos algo discutible. La minoría y la prensa estaban divididas. La Igualdad y El Combate, entre otros, abogaban por la insurrección apoyándose en que la minoría había afirmado en las Cortes que el Gobierno había violado la Constitución y el Reglamento parlamentario para montar la «dictadura de Prim». La Discusión y El Pueblo sostenían lo contrario: el parlamentarismo y la lucha legal. Ante la presión y para evitar la tan temida división del partido, tras la aprobación de la citada «proposición Romero Robledo», los pocos diputados republicanos que asistían ya a las Cortes se reunieron el 25 de diciembre, y decidieron el retraimiento parlamentario (45). Era una solución intermedia que de nada sirvió.

El atentado mortal contra el general Prim fue otra muestra de la división entre parlamentaristas e insurreccionales. Figueras, erigido otra vez líder de la minoría republicana, condenó «altamente» el asesinato y declaró: «no tenemos más que una bandera, la de la moralidad y la de la legalidad», y el que no actuara bajo dicha bandera, no era «hombre republicano». Los señalados eran los diputados intransigentes, y entre ellos los redactores de El Combate: Paul y Angulo, y Ramón Cala. Solo este último estaba en la Cámara y negó cualquier implicación en el acto. La mayoría gubernamental aprovechó la ocasión para presentar conjuntamente una reprobación del atentado y un voto de confianza al Gobierno. Figueras anunció que la minoría votaría afirmativamente a lo primero, pero que no podía dar su confianza al Ejecutivo. Añadió que la condena

(44) DSCC, núm. 320 y 324, 19 y 23.XII.1870, pp. 9241-9261 y 9335-9380.

(45) La Discusión, 25.XI.1870; El Imparcial, 26.XII.1870; y Figueras en DSCC, núm. 329, 28.XII.1870, p. 9506. 
del atentado no variaría «el propósito y la conducta de la minoría, que es combatir constantemente a un Gobierno que ha violado la Constitución».

\section{CONCLUSIÓN}

Lejos de la idea de que los republicanos pronunciaban discursos en las Cortes solo para lucir argumentos, la minoría puso en marcha una estrategia parlamentaria clara para obstruir las medidas o acuerdos de la Cámara -lo que se denomina «obstruccionismo»-, y para hacer propaganda y marcar liderazgos y comportamientos políticos. Presentaron un total de nueve proposiciones de censura entre noviembre de 1869 y diciembre de 1870. Inundaron de proposiciones los momentos clave de las Cortes, como fue el periodo previo a la discusión del proyecto constitucional, entre marzo y abril de 1869, cuando dieron a la Mesa hasta 13 proposiciones; o tras la elección de Amadeo de Saboya en noviembre de 1870. A esto sumaron interpelaciones largas, propias del «filibusterismo», de las que se encargaban Castelar y Pi y Margall. Solicitaban con excesiva frecuencia, especialmente Figueras, sobre todo después de la insurrección de octubre de 1869, la lectura del Reglamento para consumir sesiones y turnos de palabra gracias a forzadas alusiones personales. Y pedían votaciones nominales que llenaban el tiempo reglamentario e impedían avanzar en el trabajo parlamentario. A este obstruccionismo técnico sumaban el obstruccionismo físico; es decir, gritos y aplausos exagerados que dilataban los debates, enfrentamientos verbales poco cordiales con otros diputados, y el abandono de la cámara, en plena votación, para volver después en grupo. La respuesta de la mayoría para evitar el obstruccionismo, denunciado por la prensa ministerial, por algún ministro y el mismo regente Serrano, fue formar comisiones legislativas que excluían a los republicanos -lo hicieron en dos ocasiones- y suspender las sesiones de Cortes.

En la minoría hubo tres liderazgos, cuya sucesión se debió a factores externos: la aprobación de la Constitución, la insurrección de octubre de 1869, y la organización del partido en pactos. Orense introdujo el obstruccionismo como estrategia principal de la minoría republicana, y se centró en la necesidad de que el republicanismo marcara su identidad. Figueras asumió el liderazgo tras la aprobación de la Constitución, mantuvo el obstruccionismo como táctica parlamentaria, y orientó las actividades de la minoría hacia la atracción de los demócratas y la ruptura de la coalición señalando las diferencias ideológicas con los unionistas. Pi y Margall, sin dejar el obstruccionismo, asentó su liderazgo en dos pilares. Por un lado, en lugar de criticar a sus antiguos compañeros demócratas, dirigió sus ataques al Partido Progresista, al que acusó de no representar ya la voluntad nacional y de perder así su base social; todo, según él, por mantener el compromiso con la Unión Liberal. Por otro lado, trató de organizar el partido desde la minoría parlamentaria para unificar la dirección. 
El obstruccionismo técnico y físico alimentó el antiparlamentarismo de aquellos republicanos que todo lo fiaban a la revolución. Y el ansia insurreccional de estos animó a su vez al surgimiento de un republicanismo parlamentario y posibilista que se fue desarrollando desde octubre de 1869 y que dio la primera batalla en mayo de 1870, pero al que faltó la decisión de Figueras y Castelar para romper una falsa unidad del partido. Al tiempo, ese obstruccionismo que despreciaba el Parlamento y confiaba en el federalismo desde abajo, hizo imposible la vía parlamentaria de la opción política de Pi y Margall, por lo que el partido se organizó en provincias para la revolución, lo que propició el cantonalismo contra la República en 1873.

\section{BIBLIOGRAFÍA}

Aragón, MAnUEl (1986): «El control parlamentario como control político», Revista de Derecho Político, núm. 23, pp. 9-39.

Cabrera Calvo-Sotelo, Mercedes y Arranz Notario, Luis (1995): «El Parlamento en la Restauración», Hispania, núm. 189, pp. 67-98.

(1998) (coord.): Con luz y taquígrafos: el Parlamento en la Restauración (1913-1923), Madrid, Taurus.

Calero, Antonio María (1987): Estudio Preliminar a «Monarquía y democracia en las Cortes de 1869», selección de textos y estudio preliminar a cargo de este autor, Centro de Estudios Políticos y Constitucionales, Madrid.

CAstelar, Emilio (1872): Estanislao Figueras. Semblanzas contemporáneas, La Habana, t. IV.

Castro Alfín, D. (1994): «Unidos en la adversidad, unidos en la discordia: el Partido Demócrata, 1849-1868», en N. Townson (ed. lit.), El republicanismo en España (1830-1977), Madrid, Alianza Editorial, pp. 59-86.

- (2015): «Maestro y jefe. Facetas del liderazgo político de Pi y Margall», en DEMETRIO CASTRO (coord.), Líderes para el pueblo republicano. Liderazgo político en el republicanismo español del siglo XIX, Editorial de la Universidad Pública de Navarra, pp. 149-178.

DuARTe, Ángel (2001): «Historias de federales, historia republicana», Historia y Política, núm. 6, pp. 7-30.

- (2008): «Estanislao Figueras y el quimérico federalismo manso», M. PÉREZ Ledesma e I. BuRdiel, Liberales eminentes, Madrid, Marcial Pons, pp. 245-276.

DuArte, A. y Gabriel SiRvent, P. (2000): «¿Una sola cultura política republicana ochocentista en España?», Ayer, núm. 39, pp. 11-34.

EstévaneZ, Nicolás (1975): Mis memorias, Madrid, Tebas.

Fuente Monge, Gregorio L. DE LA (1993): Revolución liberal y élites revolucionarias en España (1868-1869), Madrid, Editorial Universidad Complutense de Madrid.

- (2000): Los revolucionarios de 1868. Élites y poder en la España liberal. Madrid, Marcial Pons. 
(2007): «Monarquía y República en la España revolucionaria (1868-1873)», en A. LARIO GONZÁlez (coord.), Monarquía y República en la España contemporánea, Madrid, Síntesis, pp. 205-230.

- (2015): «José María Orense: El líder demócrata y sus seguidores», en DeMETRIO CASTRO (coord.), Líderes para el pueblo republicano. Liderazgo político en el republicanismo español del siglo XIX, Editorial de la Universidad Pública de Navarra, pp. 41-97.

GABRIEL SiRVENT, P. (2004): «Pi y Margall y el federalismo popular y democrático: el mármol del pueblo», Historia social, núm. 48, pp. 49-68.

GONZÁlez de ZÁrATE LORENTE, RoBERTO (2012): «El obstruccionismo parlamentario», Asamblea: revista parlamentaria de la Asamblea de Madrid, núm. 27, p. 183-202.

HENNESY, C.A.M. (1966): La república federal en España. Pi y Margall y el movimiento republicano federal, 1868-1874, Madrid, Aguilar.

Jover Zamora, J. M. (1991): Realidad y mito de la Primera República: Del «Gran Miedo» meridional a la utopía de Galdós, Madrid, Espasa-Calpe.

LARIO, Ángeles (2007): «La Monarquía herida de muerte. El primer debate Monarquía/República en España», en A. LARIo GonzÁlez (coord.), Monarquía y República en la España contemporánea, Madrid, Síntesis, pp. 183-204.

LÓPEZ AgUILAR, JuAN FERNANDO (1991): Minoría y oposición en el parlamentarismo. Una aproximación comparativa, Madrid, Congreso de los Diputados.

MarCuello, J. I. (2013): «El principio de la autonormatividad reglamentaria de las Cortes: su controversia en los inicios del régimen parlamentario en la España liberal (1810-1864)», Historia Constitucional, núm. 14, pp. 199-229.

Marcuello, J. I. y Pérez Ledesma, M. (1996): «Parlamento y poder ejecutivo en la España contemporánea (1810-1931)», Revista de Estudios Políticos, núm. 93, pp. 17-38.

Martínez CuAdrado, M. (1963): «La elección general para Cortes Constituyentes de 1869», Revista de Estudios Políticos, núm. 132, pp. 65-102.

Miguel GonzÁlez, Miguel (2007): La pasión revolucionaria: culturas políticas republicanas y movilización popular en la España del siglo XIX, Madrid, Centro de Estudios Políticos y Constitucionales.

Mira Abad, Alicia (2011): «La monarquía imposible: Amadeo de Saboya y María Victoria», E. LA PARRA LÓPEZ (coord.), La imagen del poder. Reyes y regentes en la España del siglo XIX, Madrid, Síntesis.

Molas, IsIDRE (1989): «La oposición en el parlamentarismo mayoritario», Revista del Centro de Estudios Constitucionales, núm. 2, pp. 47-64.

Montero Gibert, José Ramón y García Morillo, JoAquín (1984): El control parlamentario, Madrid, Tecnos.

Morayta, Miguel (1895): Historia general de España, desde los tiempos antehistóricos hasta la actualidad, Madrid, tomo VIII.

Oliet PalÁ, A. (1989): El conflicto social y la legitimación de la monarquía ante la revolución de 1868, Madrid, Ministerio de Trabajo y Seguridad Social.

PAVón, Jesús (1972): España y la cuestión romana, Madrid, Moneda y Crédito. 
Pérez RoldÁn CARMen (2001): El Partido Republicano Federal, 1868-1874, Madrid, Endymion.

Peyrou Tubert, F. (2007): «Los significados de "República". Republicanos y demócratas en el periodo isabelino», en A. LARIO (coord.), Monarquía y República en la España contemporánea, Madrid, Biblioteca Nueva, pp. 155-182.

- (2008): «José María Orense: Un aristócrata entre republicanos», MANUEL PÉREZ Ledesma e IsABel Burdiel (eds.): Liberales eminentes, Madrid, Marcial Pons.

(2011): «Presentación. El republicanismo en la historiografía», Historia y Política, núm. 25, pp. 11-27.

Piqueras Arenas, J. A. (1992): La revolución democrática (1868-1874): cuestión social, colonialismo y grupos de presión, Madrid, Ministerio de Trabajo y Seguridad Social.

Rey Reguillo, F. Del y Martorell, M. (2006): «El parlamentarismo liberal y sus impugnadores», Ayer, n. ${ }^{\circ}$ 63, pp. 23-52.

RISPA Y PERPIÑ́, FRANCISCO (1932): Cincuenta años de conspirador. Memorias político-revolucionarias, 1853-1903, Barcelona, Vilella.

RUBio, JAVIER (2011): «La candidatura Hohenzollern de 1870 de nuevo a debate», Bulletin d'histoire contemporaine de l'Espagne, núm. 46, pp. 227-246

SÁEz Miguel, Pablo (2011): «Espartero o el cincinato español. Historia de la candidatura a Rey del Duque de la Victoria (1868-1870)», Berceo, núm. 160, pp. 227260.

Sagrera, A. DE (1959): Amadeo y María Victoria: reyes de España, 1870-1873, Palma de Mallorca.

SÁNChez NAVARRo, ÁNGel J. (1995): «Control parlamentario y minorías», Revista de Estudios Políticos, núm. 88, pp. 223-255.

- (1997): La oposición parlamentaria, Madrid, Congreso de los Diputados.

SERRA CRISTÓBAL, RoSARIO (2009): «Pequeñas minorías y control parlamentario», Corts: Anuario de derecho parlamentario, núm. 21, pp. 99-120.

SuÁRez Cortina, Manuel (2011): «El republicanismo en la España liberal (18201931): una aproximación historiográfica», Bulletin d'histoire contemporaine de l'Espagne, núm. 46, pp. 11-42.

TORRES Muro, IGNACIO (1993-1994): «El obstruccionismo, un arma de las minorías», Revista de la Facultad de Derecho de la Universidad Complutense, núm. 83, pp. 65-375.

VARela Suanzes-Carpegna, Joaquín (2006): «La Monarquía en las Cortes y en la Constitución de 1869», Historia constitucional, núm. 7, http://hc.rediris.es/07/index.html

Vera y GONZÁlez, EnRIQUe (1886): Pi y Margall y la política contemporánea, Barcelona, La Academia, 2 vols.

Villalba Hervás, Manuel (1899): De Alcolea a Sagunto, Madrid, Lib. Victoriano Sánchez.

Vilches, JoRge (2001a): Progreso y libertad. El partido progresista en la revolución liberal española, Madrid, Alianza Editorial. 
(2001b): «Pi y Margall, el hombre sinalagmático», Historia y Política, núm. 6, pp. 57-90.

(2001c): Emilio Castelar, la patria y la república, Madrid, Biblioteca Nueva.

(2012): «El posibilismo republicano ante el catolicismo durante el reinado de Alfonso XII. A propósito de los sucesos de la Santa Isabel (1884)», Hispania, núm. 214, pp. 535-564.

(2015): «La oratoria en las urnas. El Partido Posibilista y el liderazgo de Emilio Castelar (1874-1894)», en DEMETRIO CASTRO (coord.), Líderes para el pueblo republicano. Liderazgo político en el republicanismo español del siglo XIX, Editorial de la Universidad Pública de Navarra, pp. 123-147. 
